\title{
A Laboratory Study of the Collapse Behaviour of a Compacted Sabkha Soil
}

\author{
O.Y. Debbab, B. Moussai, A. Messad
}

\begin{abstract}
Sabkha soils are saline sediments, which can withstand high loads in dry conditions, but upon wetting, they exhibit significant deformation and low shear strength and hence pose great challenge to engineers. This paper investigates the collapsibility of a compacted sabkha soil of Chott El-Hodna (Algeria) using a modified oedometer, which allows water to percolate through the soil sample. The collapsibility tests were conducted on samples compacted at a variety of values of fluid contents and relative compactions using sabkha brine. The standard Proctor tests were performed using distilled water and sabkha brine, and the compaction characteristics were determined using conventional water content and fluid content methods. The results indicate that the conventional water content procedure used to plot the compaction curve overestimates the maximum dry unit weight and underestimates the optimum moisture content. The degree of collapsibility varies from moderate to severe depending on the compaction conditions (i.e. relative compaction, initial fluid content, degree of saturation). The collapse potential increases with increasing applied load and compaction fluid content and with decreasing relative compaction. Moreover, it has been demonstrated that the use of a conventional oedometer underestimates the collapse potential of saline soils.
\end{abstract}

Keywords: collapse potential, fluid content, Sabkha soil, saline soils, water content.

\section{Introduction}

With recent economic development in Algeria, extensive infrastructure projects (highways, roads, railways, etc.) are planned to be constructed over areas covered with sabkha soils. However, many infrastructures built through sabkha areas are suffering from severe damage caused by the presence of salts in the soil, including cracks and differential settlements. Severe damage to buildings and roads constructed on sabkha soils in Libya and Saudi Arabia were reported by Khan \& Hasnain (1981) and Amin (2004). Moayed et al. (2010) reported several deteriorations of recently built roads (raveling, cracking, rutting and formation of landslides) in the region of Taleghan (Iran).

Compacted fills of saline soils employed in the construction of roadways, railways, earthen dams, etc. may experience water penetration after inundation and therefore exhibit problematic collapse potential, which can cause considerable damage to the structure. Therefore, predicting the collapse potential of this type of soils is important for the design of engineering structures.

Al-Amoudi \& Abduljauwad (1995) performed collapse potential tests on surficial undisturbed sabkha soil of Saudi Arabia and concluded that the collapse is mainly related to the dissolution of salts and it does not occur instantaneously as in loessial soils for example, but requires continuous percolation of water to enhance the dissolution of the cementing agent.
Messad \& Moussai (2016b) studied the collapse behaviour of a saline marly soil using conventional and modified oedometers, and concluded that the collapse potential of this type of soils can be obtained only by percolation of water through the soil sample.

Moreover, Mansour et al. (2008) performed standard Proctor tests on marly soil from the Dead sea area and reported that the optimum water content decreases and the maximum unit weight increases as the water salinity increases. Similar results were found by Alainachi \& Alobaidy (2010) \& Shariatmadari et al. (2011). In these studies, the compaction curve was plotted based on the conventional water content definition, which does not take the presence of salts in the soil into consideration.

The objective of this study is to investigate the collapse behaviour of a compacted sabkha soil of Chott ElHodna (Algeria) using a modified oedometer that allows water to percolate through the soil sample. To achieve this, an extensive experimental program was conducted, which included particle size distribution, specific gravity, compaction and collapsibility tests. The effect of water salinity on the compaction characteristics of sabkha soil was also highlighted.

\section{Materials and Their Characteristics}

The material used in this study is silty sand collected from the sabkha of Chott El Hodna (Fig. 1). Disturbed samples were retrieved from test pits dug in the sabkha area.

O.Y. Debbab, Ph.D. Student, University of Science and Technology Houari Boumediene, Algiers, Algeria.

B. Moussai, Professor, University of Science and Technology Houari Boumediene, Algiers, Algeria. e-mail: bmoussai@yahoo.ca.

A. Messad, Lecturer, Yahia Fares University, Media, Algeria.

Submitted on April 4, 2019; Final Acceptance on March 24, 2020; Discussion open until September 30, 2020.

DOI: $10.28927 /$ SR.432181 


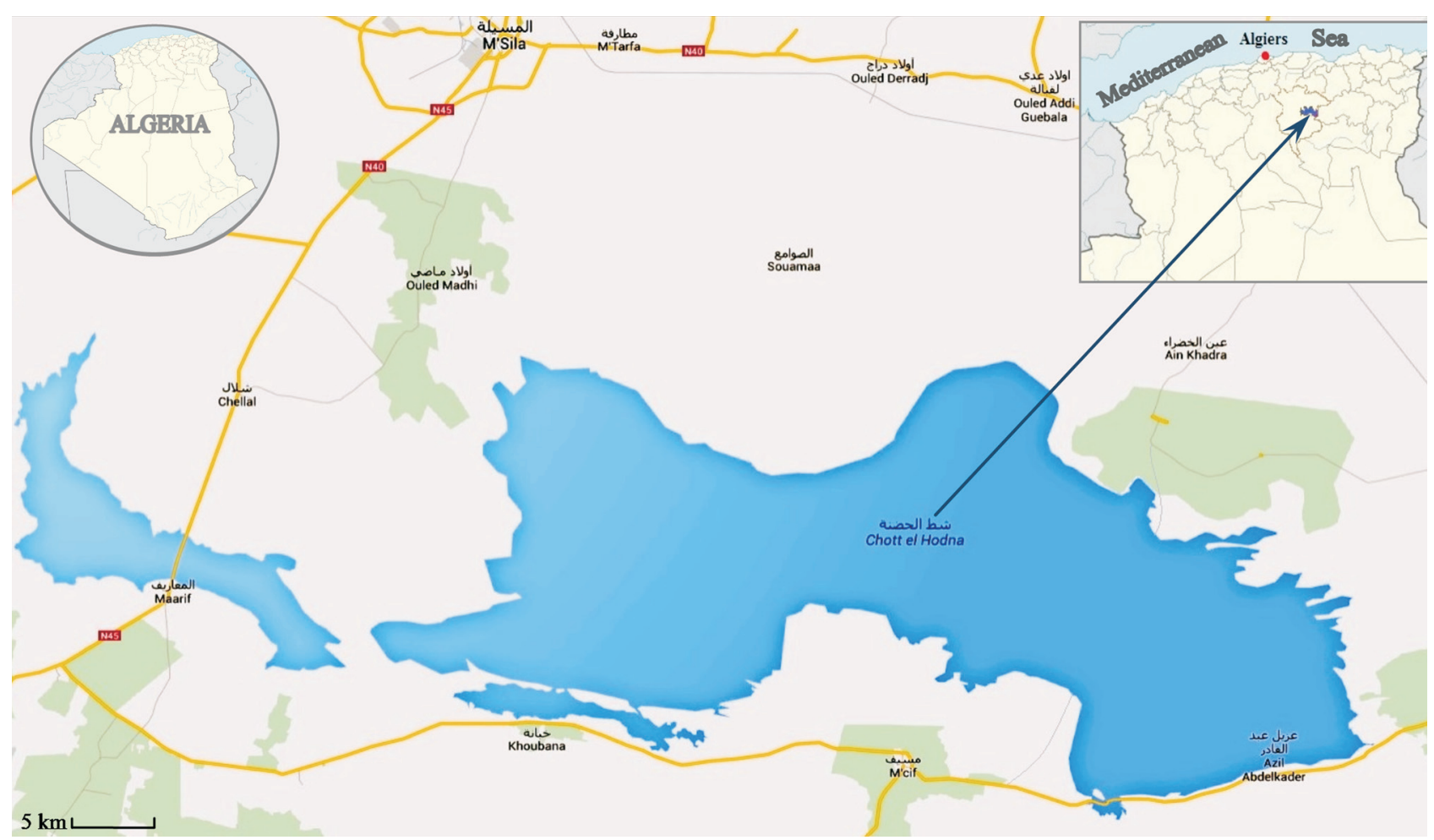

Figure 1 - Chott El Hodna area.

The depth of the test pits was about $0.6 \mathrm{~m}$ from the ground surface.

The sabkha brine contained approximately $26 \%$ (by weight of brine) dissolved salts, and its specific gravity was 1.22. The chemical analysis of sabkha brine is given in Table 1 .

The particle size distribution shown in Fig. 2 indicates that the sabkha soil is composed of $82 \%$ sand and $18 \%$ fines (silt and clay). This soil is classified as SM according to the Unified Soil Classification System (USCS). Its specific gravity is 2.7. The X-ray diffraction analysis indicated that the soil is mainly composed of quartz and calcite (Fig. 3).

Specific gravity and particle size distribution were performed based on the procedures outlined in ASTM D854-05 (2005) and ASTM D422-63 (2007), respectively.

The moisture content of sabkha soil is determined based on the fluid content $\left(\omega_{f}\right)$ definition, which is the ratio between the brine weight and the dry weight of soil solids (Messad \& Moussai, 2016a). This definition takes into consideration the presence of salt and is given by the following relationship:

$$
\omega_{f}=\frac{w_{b}}{w_{s}}=\frac{w-w_{d}}{w_{d}-w r}=\frac{\omega_{c}}{1-r-r \omega_{c}}
$$

with $r=\frac{w_{s a}}{w_{b}}=$ salinity, $W_{b}$ the weight of brine, $W_{s a}$ the weight of salt, $W$ the wet weight of soil (including salt), $W_{d}$ the dry weight of soil (including salt), $W_{\omega}=W-W_{d}$ the weight of distilled (fresh) water, $W_{s}$ the weight of soil solids (excluding salt) $=W-W_{b}=\frac{w_{d}-r w}{1-r}=$ and $\omega_{c}$ the conventional water content $=\frac{w-w_{d}}{w_{d}}$.

\section{Compaction}

Standard Proctor tests were conducted on the sabkha soil to evaluate the effect of water salinity on the compaction characteristics (optimum moisture content and maximum dry unit weight). The Standard Proctor tests were performed based on the procedure outlined in ASTM D698 (2007) on washed soil samples passing No. 4 sieve using distilled water and sabkha brine.

The compaction characteristics were determined using conventional water content and fluid content methods (Table 2 and Fig. 4).

Table 1 - Chemical analysis of sabkha brine (Messad \& Moussai, 2016a).

\begin{tabular}{cccccc}
\hline $\mathrm{pH}$ & $\mathrm{K}^{+}(\mathrm{g} / \mathrm{L})$ & $\mathrm{Ca}^{2+}(\mathrm{g} / \mathrm{L})$ & $\mathrm{Mg}^{2+}(\mathrm{g} / \mathrm{L})$ & $\mathrm{Na}^{+}(\mathrm{g} / \mathrm{L})$ & $\mathrm{Cl}^{-}(\mathrm{g} / \mathrm{L})$ \\
\hline 7.2 & 19.05 & 25.92 & 15.55 & 94.59 & 208.49 \\
\hline
\end{tabular}




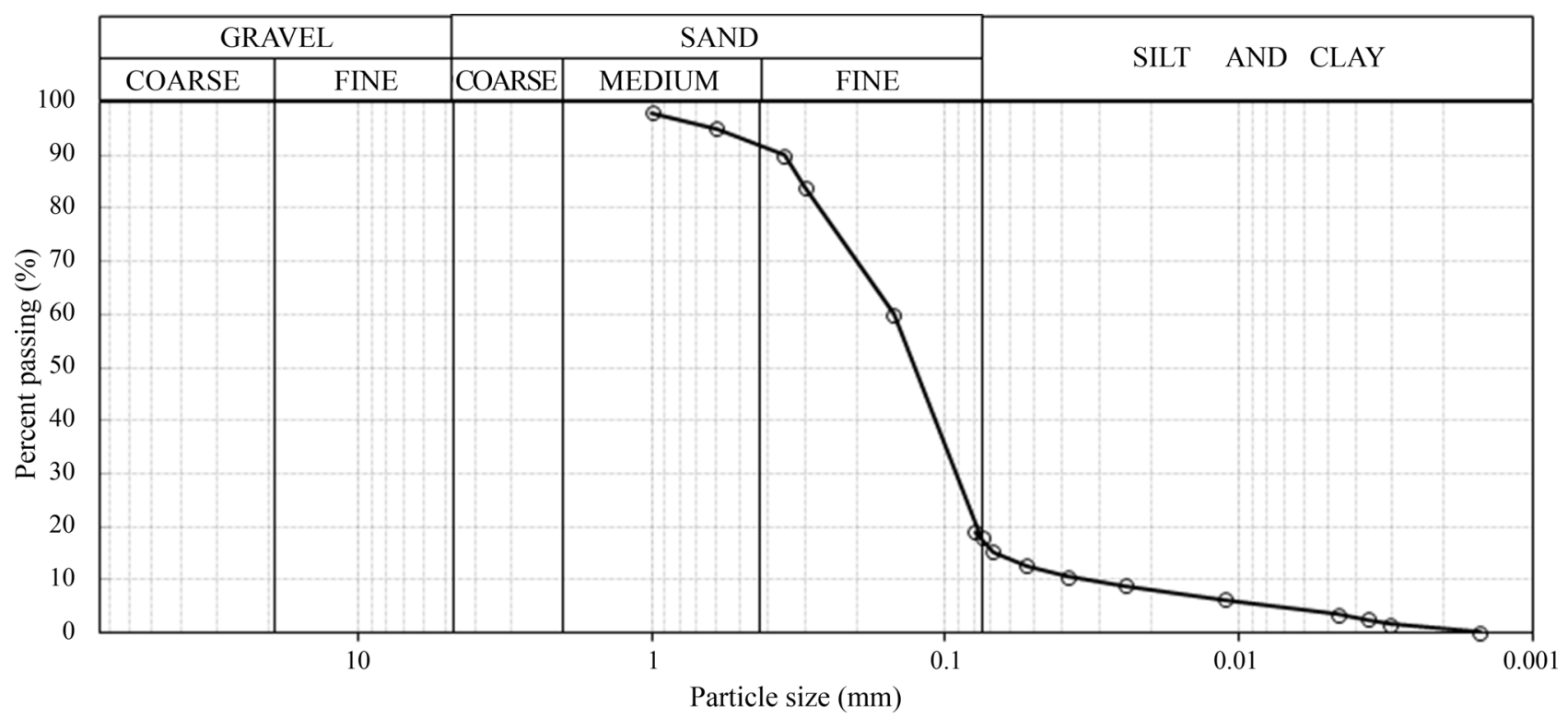

Figure 2 - Particle size distribution of the sabkha soil.

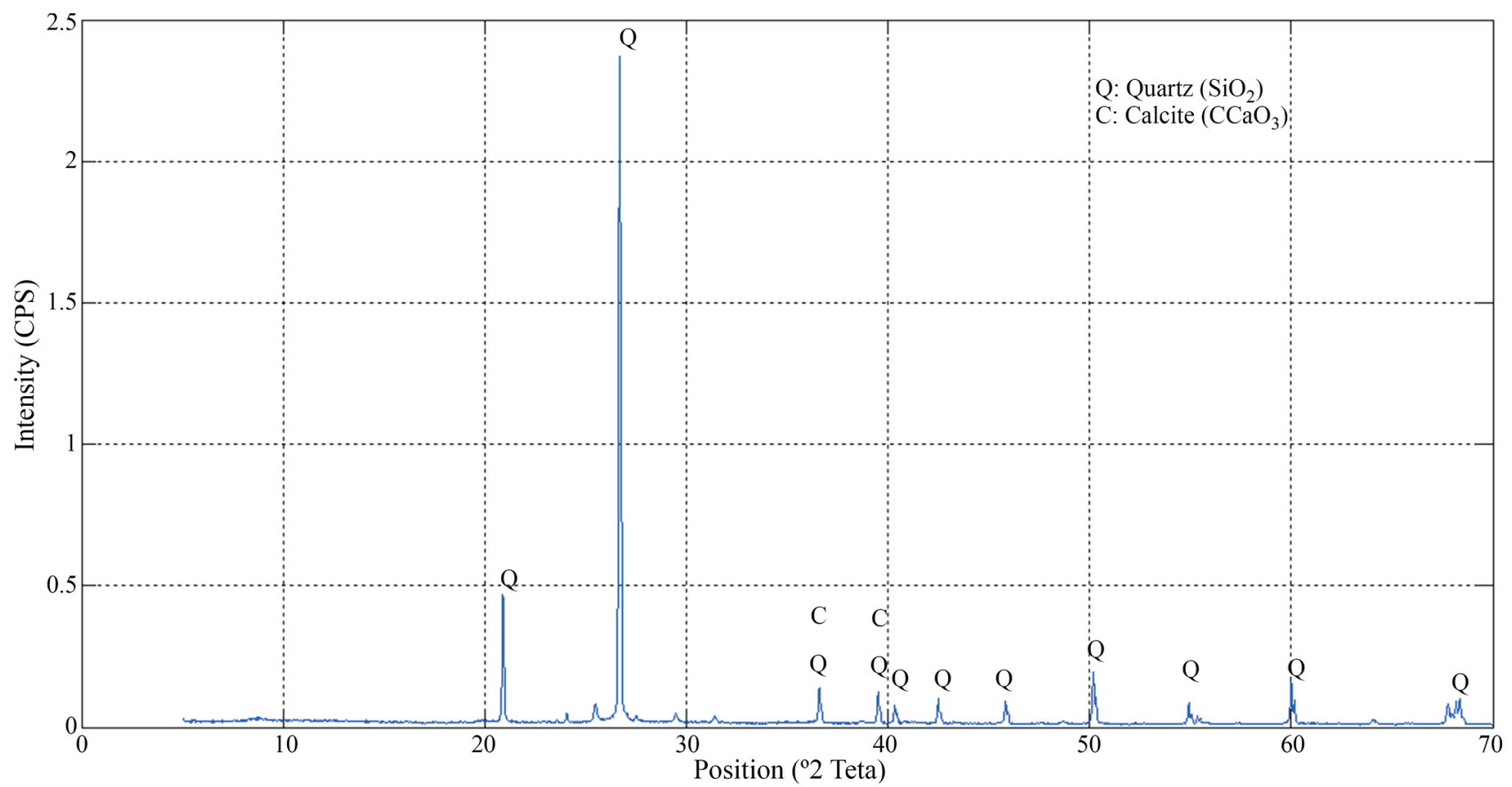

Figure 3 - X-ray diffraction of the sabkha soil.

Table 2 - Compaction test results.

\begin{tabular}{lccccc}
\hline Type of fluid & \multicolumn{2}{c}{ Conventional water content procedure } & & \multicolumn{2}{c}{ Fluid content method } \\
\cline { 2 - 3 } \cline { 5 - 5 } & $\gamma_{d-\text { max }}\left(\mathrm{kN} / \mathrm{m}^{3}\right)$ & $\omega_{c-\text { opt }}(\%)$ & & $\gamma_{d-\max }\left(\mathrm{kN} / \mathrm{m}^{3}\right)$ & - \\
\hline Distilled water & 18.8 & 11.6 & & - & $\omega_{\text {fopt }}(\%)$ \\
Sabkha brine & 19.7 & 10.3 & 19.1 & 14 \\
\hline
\end{tabular}

It can be seen that for the soil compacted using sabkha brine, the maximum dry unit weight obtained from fluid content procedure is lower than that obtained from conventional water content procedure. However, the optimum moisture content obtained from fluid content procedure is higher than that obtained from conventional water content procedure. 


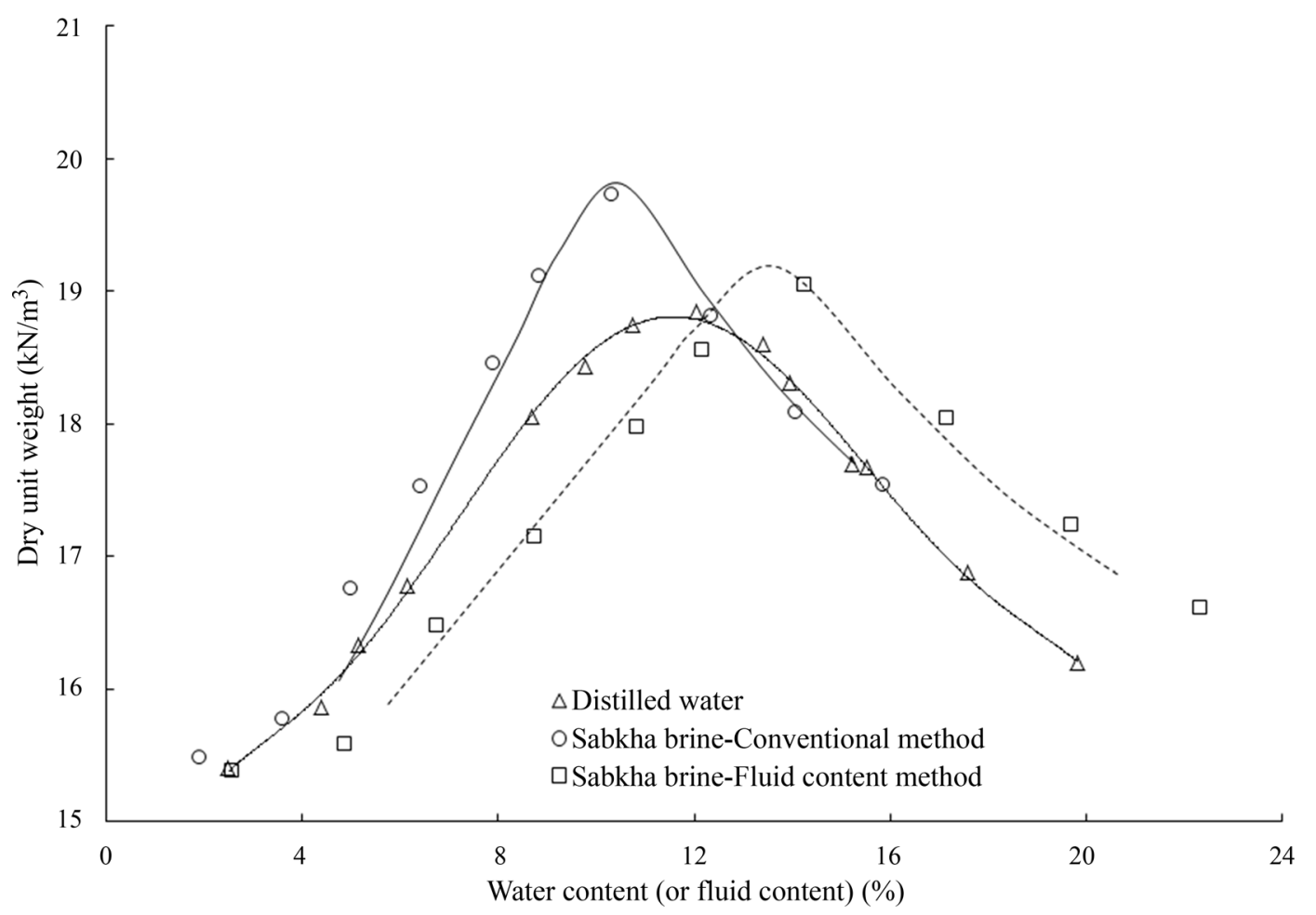

Figure 4 - Compaction test curves.

When the conventional water content procedure is used to plot the compaction curve, the maximum dry unit weight increases by about $5 \%$ and the optimum moisture content decreases by about $11 \%$ compared to those obtained using distilled water. These results are in accordance with those reported by Mansour et al. (2008).

However, when the fluid content method is used to plot the compaction curve, the maximum dry unit weight decreased by about $3 \%$ and the optimum moisture content increased by about $36 \%$, compared to those obtained using the conventional water content procedure.

\section{Collapse Potential Measurement}

The conventional oedometer cannot be used to detect the collapse potential of saline soils, which requires continuous percolation of water to dissolve the salty-cemented matrix. Thus, the fixed-ring oedometer of $70 \mathrm{~mm}$ internal diameter and $20 \mathrm{~mm}$ height was modified in such a way that it could function as a constant-head permeameter. This is accomplished by making a hole in the side of the metal cylinder to serve as an outlet for the percolating water in order to keep the water head constant as shown in Fig. 5. The existing hole in the bottom of the consolidation cell is used as water inlet. Therefore, the water can flow from the bottom to the top of the sample.

To ensure a constant head, the water level in tank 1 is regulated by a water supply from tank 2 and the excess water in tank 1 is drained as shown in Fig. 5. The volume of water in tank 2 was always kept more than the seeping wa-

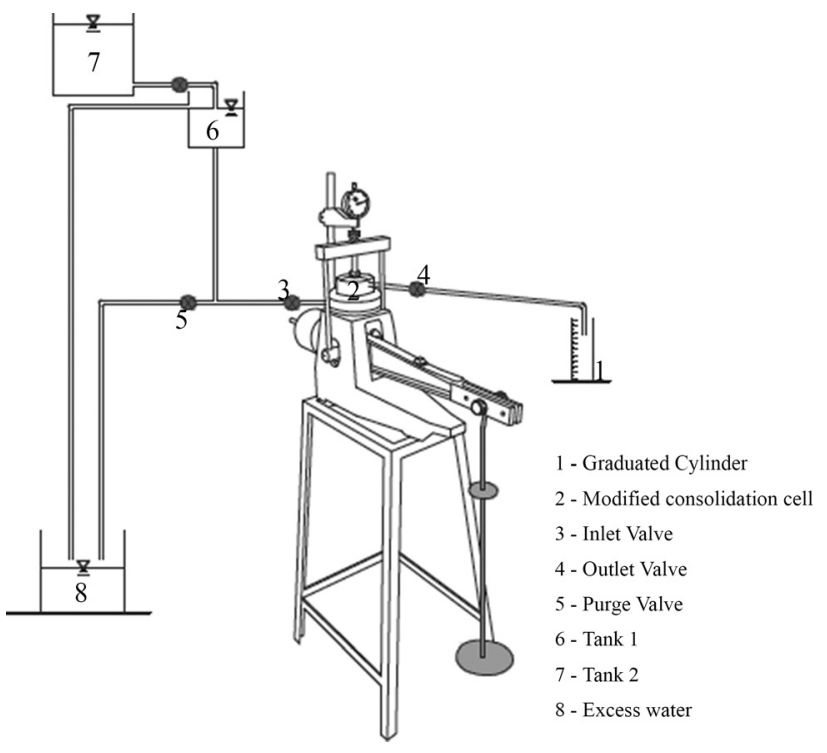

Figure 5 - Modified oedometer (Messad \& Moussai, 2016b).

ter through the sample. The hydraulic gradient used is 20 (Messad \& Moussai, 2016b).

The collapsibility tests were conducted using single oedometer method on specimens compacted in the oedometer ring, $70 \mathrm{~mm}$ in diameter and $20 \mathrm{~mm}$ thick. The specimens were prepared at different values of relative compaction and fluid content using as reference the unit weight and fluid content obtained at the optimum of Standard Proctor test (Fig. 6). 


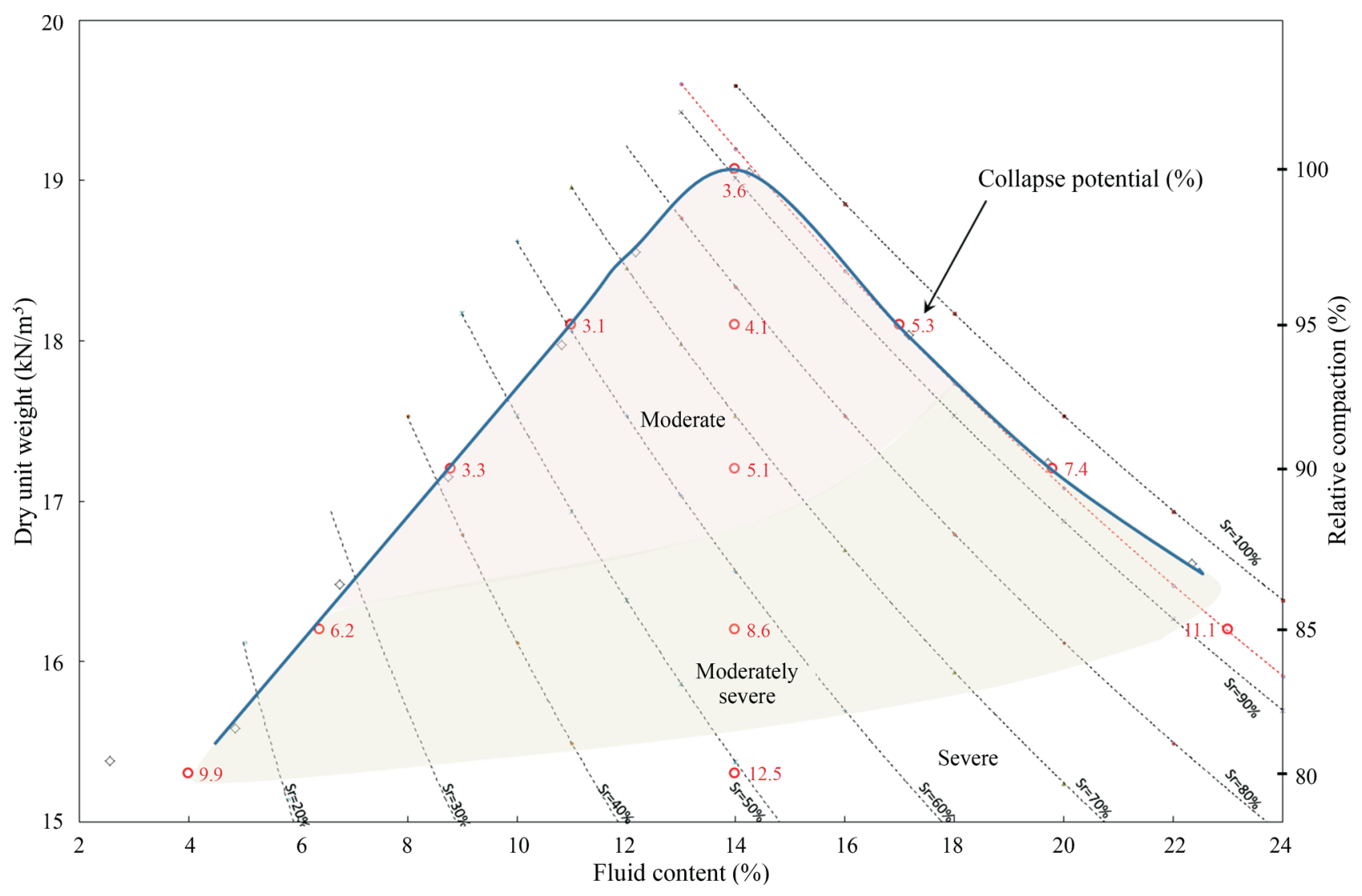

Figure 6 - Contours of equal collapse potential on $\gamma_{d}-\omega$ plane measured at $200 \mathrm{kPa}$.

It should be noted that sabkha soils in the field are subjected to repeated drying and wetting cycles due to climate conditions in the sabkha area, hence the oedometer ring containing the compacted soil specimen was oven dried prior to testing. Then the collapsibility tests were performed using the modified oedometer (Fig. 5). The sample was first subjected to a seating stress of $5 \mathrm{kPa}$ followed by incremental loads up to the desired sustained pressure (e.g. $200 \mathrm{kPa}$ ). Then, the oedometer cell containing the soil specimen was filled with distilled water from the bottom up using small hydraulic head $(0.2 \mathrm{~m})$ to prevent the trapping of air in the specimen. The inlet valve was closed after oedometer cell filling and the deformation of the specimen was recorded with respect to time until equilibrium. This phase allows measuring the specimen collapse potential before the leaching process.

When the sample ceased to undergo further deformation, the inlet valve was opened and the fluid was allowed to percolate through the specimen until the salinity of the seeping fluid became negligible $(0.1 \%)$. This phase allows measuring the specimen collapse potential after leaching under the sustained pressure.

Thereafter, the inlet valve was closed, while keeping the oedometer cell filled with water and the applied load was increased incrementally until the end of the loading process in the same manner as the standard consolidation test. The load increments used were: $12.5,25,50,100,200$, 400, 800 and $1600 \mathrm{kPa}$. Each load was maintained until the sample deformation reached equilibrium. The unloading of the sample was proceeded after the completion of the loading process.

Several oedometer tests were conducted on samples compacted over a range of fluid contents $\left(\omega_{\text {fopt }}-10\right.$ to $\omega_{\text {fopt }}+$ 9) and relative compactions $\left(R C=\gamma_{d} / \gamma_{d-\max }=80\right.$ to $\left.100 \%\right)$. The samples were leached with distilled water under an applied pressure of $200 \mathrm{kPa}$, which is used to define the collapse index $\left(I_{e}\right)$ according to ASTM D 5333 (Table 3). Three farther tests were performed on samples compacted at the optimum of Proctor and leached under sustained pressures of $50 \mathrm{kPa}, 100 \mathrm{kPa}$ and $200 \mathrm{kPa}$ to investigate the effect of the stress level on the collapse potential of the saline soil.

Table 3 - Classification of Collapse Index, $I_{e}$.

\begin{tabular}{lc}
\hline Degree of collapse & Collapse index $(\%)$ \\
\hline None & 0 \\
Slight & 0.1 to 2.0 \\
Moderate & 2.1 to 6.0 \\
Moderately severe & 6.1 to 10.0 \\
Severe & $>10$ \\
\hline
\end{tabular}


The collapse potential is determined using the relationship given by ASTM D 5333:

$$
I_{c}=\frac{\Delta e}{1+e_{0}} \times 100
$$

where: $\Delta e$ is the reduction in void ratio due to wetting, and $e_{0}$ is the initial void ratio. The collapse index $\left(I_{e}\right)$ is the collapse potential determined at $200 \mathrm{kPa}$.

\subsection{Results and discussion}

Figure 6 presents the collapse potential values and contours of equal collapse potential plotted on the $\omega_{f}-\gamma_{d}$ plane for all tested specimens along with the Standard Proctor compaction curve obtained using the fluid content method. The compression curves obtained using the modified oedometer at different fluid contents and dry unit weights are shown in Fig. 7.
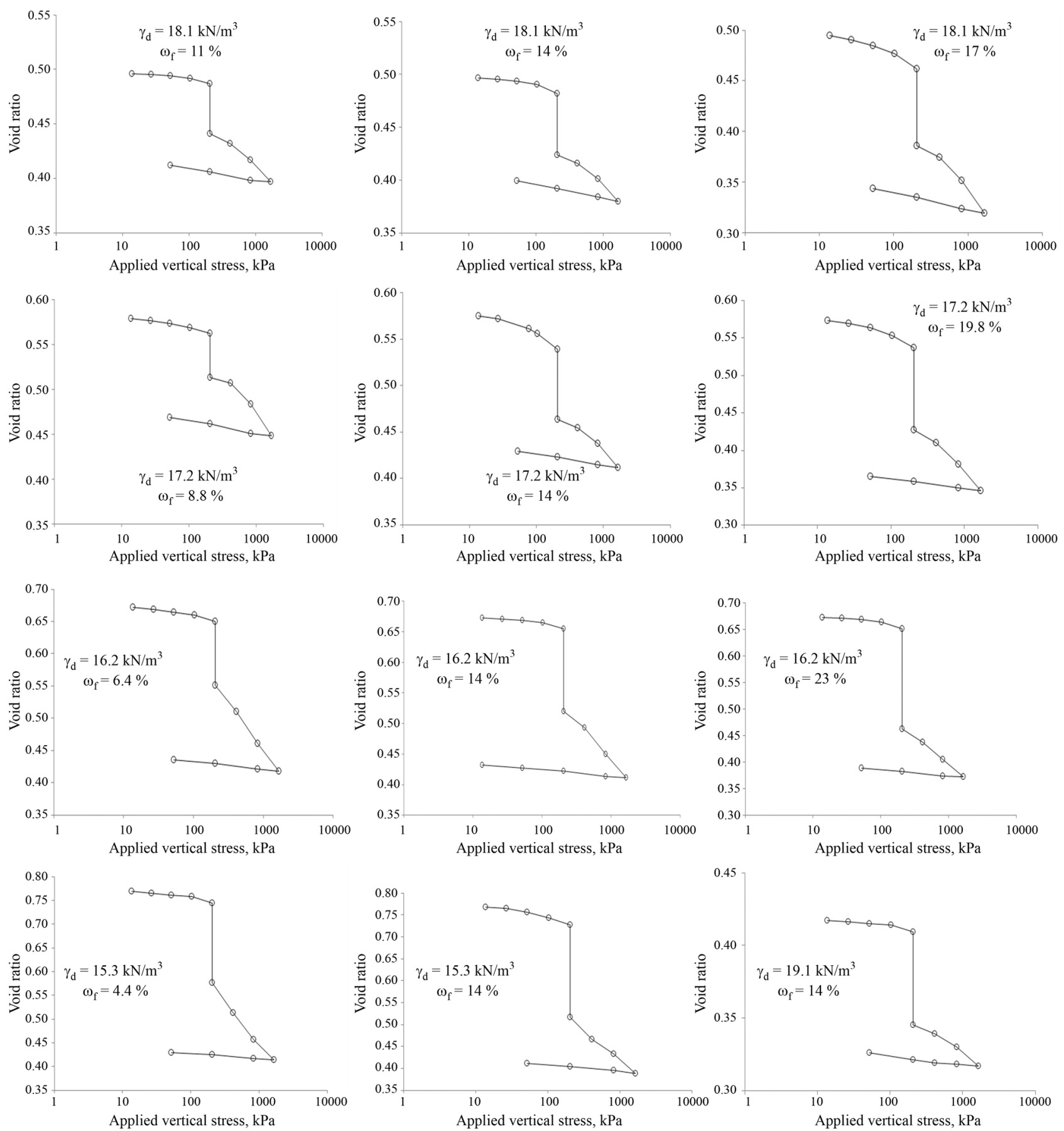

Figure 7 - Void ratio vs. applied stress curves from modified oedometer tests. 
Based on these results, the following remarks can be drawn:

- The Proctor compaction curve indicates that the optimum fluid content is $14 \%$ and the maximum dry unit weight is $19.1 \mathrm{kN} / \mathrm{m}^{3}$.

- Three regions of collapse potential are identified: moderate, moderately severe and severe according to ASTM (2003) (Table 3).

- The collapse potential values vary from $3.1 \%$ (moderate degree of collapsibility) to $12.5 \%$ (severe degree of collapsibility) depending on the compaction conditions (i.e. relative compaction, initial fluid content, degree of saturation).

- The soil is more collapsible on the wet side than on the dry side of optimum. This may be due to the increase of the amount of salt in the pores of soil compacted on the wet side of optimum.

- For specimens having similar initial degree of saturation of about $93 \%$ (i.e. along the wet side of the compaction curve), the collapse potential increases as the relative compaction decreases. Note that the degree of saturation is determined based on the fluid content method.

- For specimens compacted at the Standard Proctor energy, the collapse potential decreases as the relative compaction increases until a minimum value of $3.1 \%$ corresponding to a relative compaction of $95 \%$ and a fluid content of $11.0 \%\left(\omega_{\text {fopt }}-3 \%\right)$, beyond which it increases (Fig. 8).

- For specimens having similar fluid content of compaction, the collapse potential increases as the relative compaction decreases (Fig. 9). This result agrees well with that reported by many authors for loessial soils such as Lawton et al. (1989) and Lawton et al. (1992).

- For specimens compacted at the same relative compaction, the collapse potential increases as the fluid content increases (Fig. 10), which is contrary to the case of loessial soil flooded with distilled water where the collapse potential decreases as the water content of compac-

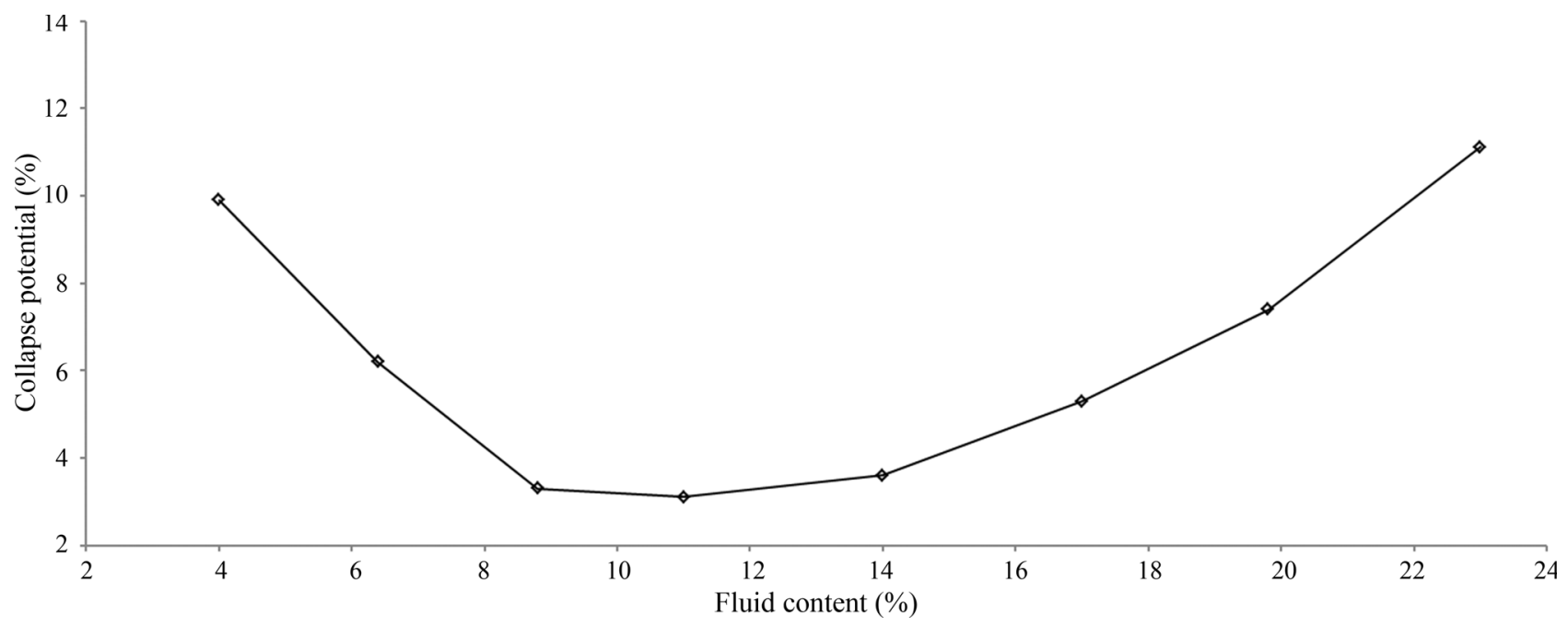

Figure 8 - Collapse potential vs. as compacted fluid content along the compaction curve.

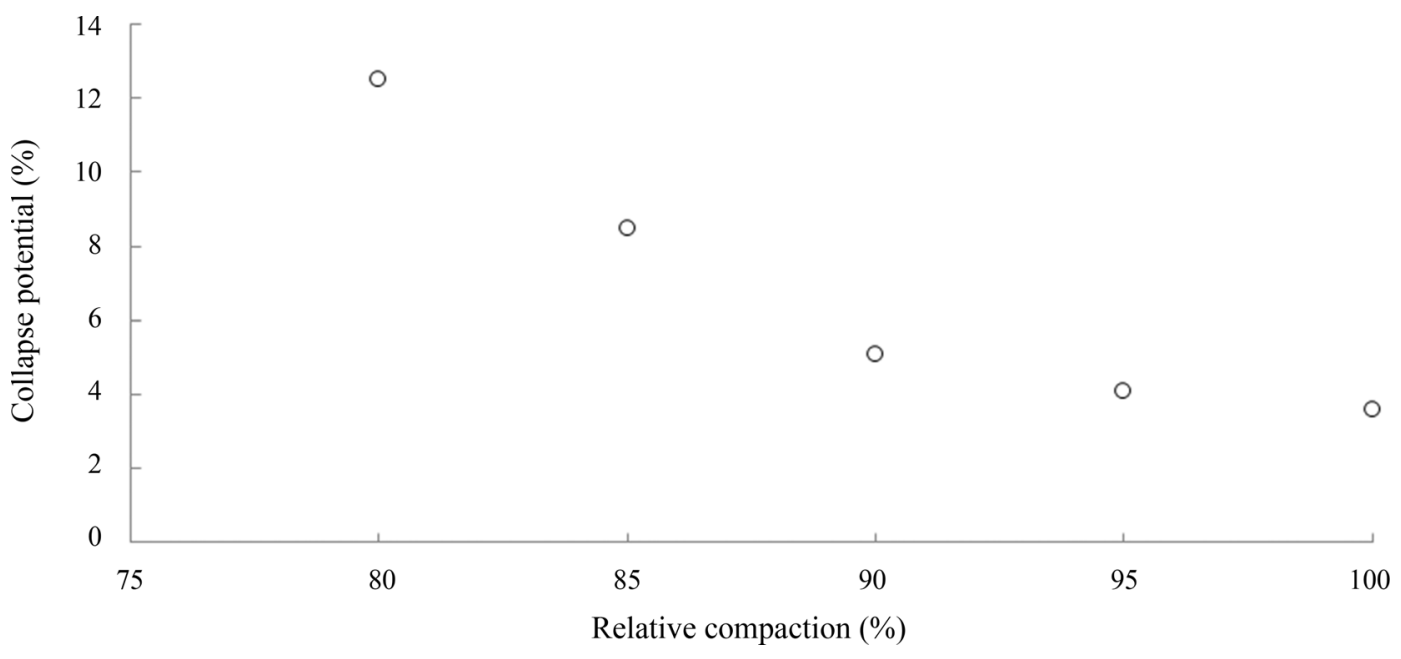

Figure 9 - Collapse potential vs. relative compaction for the fluid content of $14 \%$. 


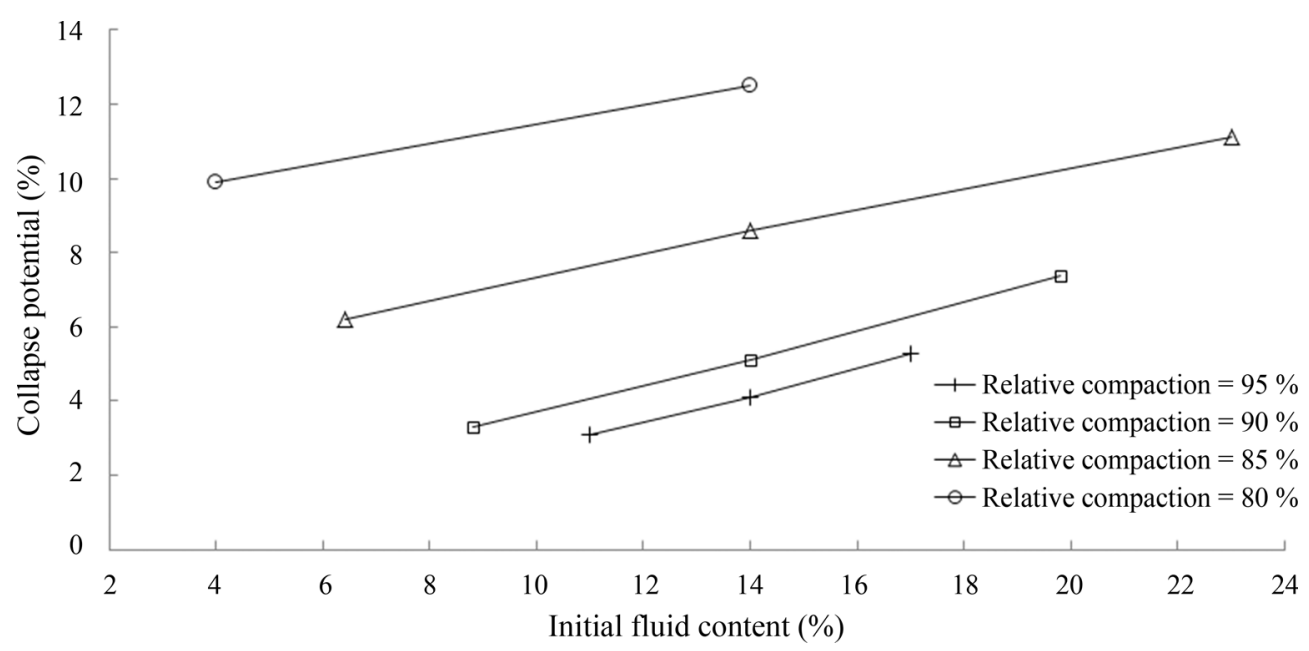

Figure 10 - Collapse potential vs. initial fluid content at different relative compactions.

tion increases (Lawton et al., 1989). This can be attributed to the increase of the amount of salt in the specimen with increasing fluid content of compaction, which leads to the increase of collapsibility after wetting and leaching process.

Figure 11a presents an example of the collapse potential vs. the time of flooding indicating the amounts of collapse potential caused by flooding with and without percolation of fluid through the soil specimen, and Fig. 11b presents the collapse potential vs. the time of flooding for all tested specimens.

It can be seen that the collapse potential reaches equilibrium after about 1 to 4 days of flooding without percola- tion and after about 7 to 18 days of flooding with percolation depending on the compaction conditions (i.e. relative compaction, initial fluid content). The results indicate that the flooding without percolation detects only partial collapse potential for saline soils and the total collapse potential can be obtained only by percolation. The amount of collapse potential due to percolation was found to be about 10 to $30 \%$ of the total collapse potential.

In order to evaluate the effect of the sustained pressure on the collapse potential, the soil compacted at optimum fluid content and maximum dry unit weight was tested for three sustained pressures: $50 \mathrm{kPa}, 100 \mathrm{kPa}$ and $200 \mathrm{kPa}$. The results indicate that the collapse potential in-

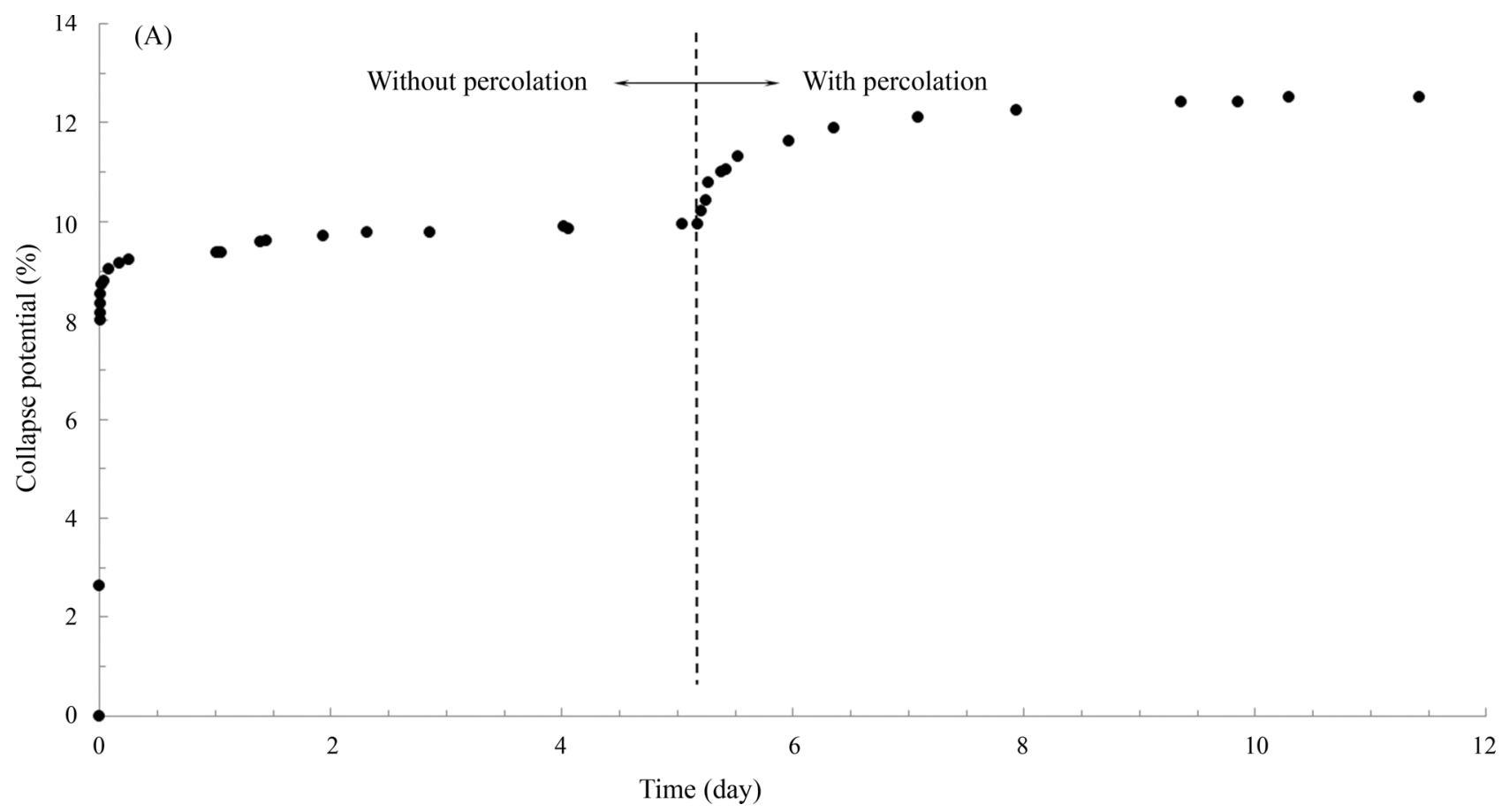

Figure 11 - a: Collapse potential vs. time of flooding for the specimen having: $\gamma_{d}=15.3 \mathrm{kN} / \mathrm{m}^{3}$ and $\omega_{f}=14 \%$. 


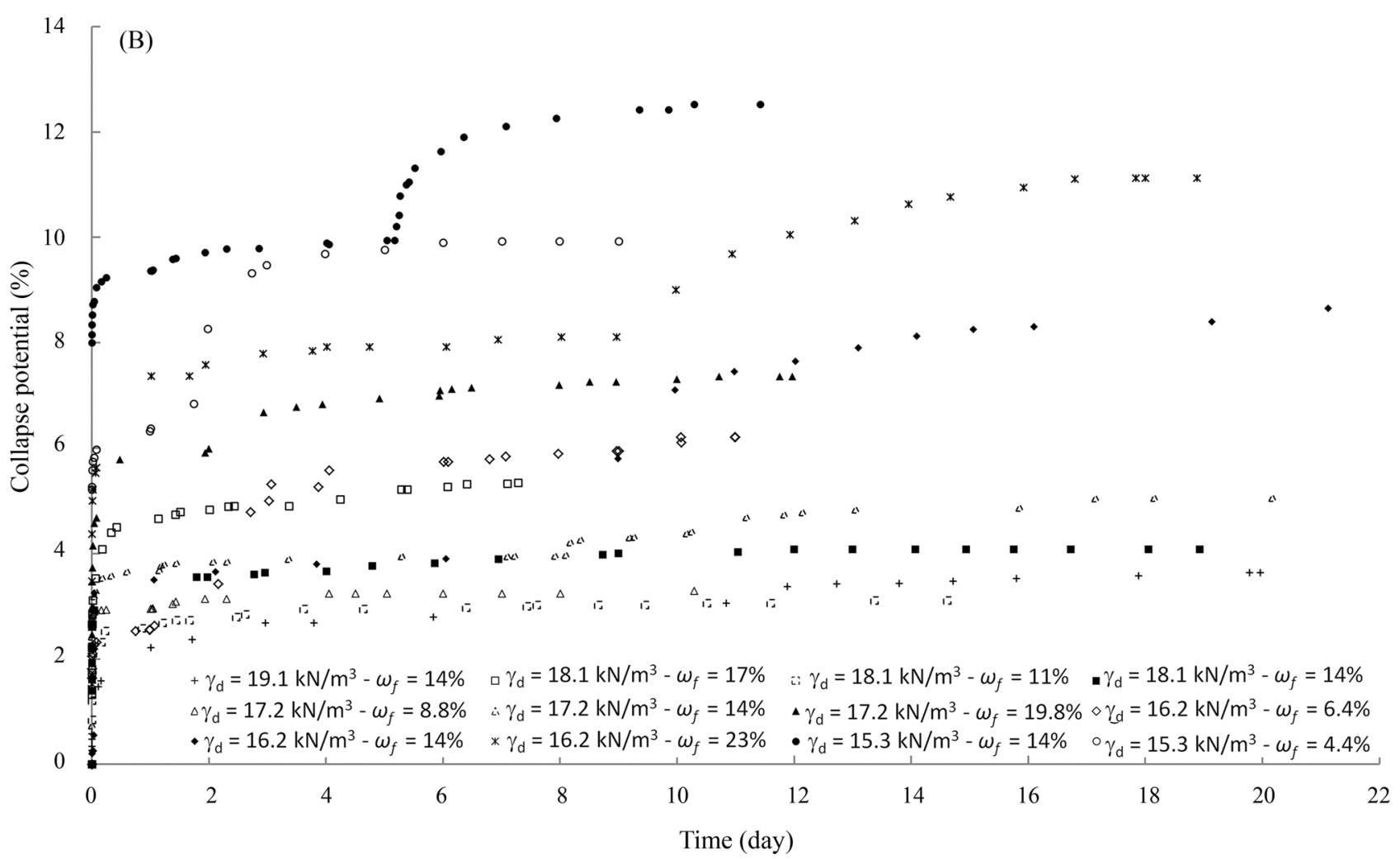

Figure 11 - b: Collapse potential vs. time of flooding for soil specimens of varying unit weight $\left(\gamma_{d}\right)$ and fluid content $\left(\omega_{f}\right)$.

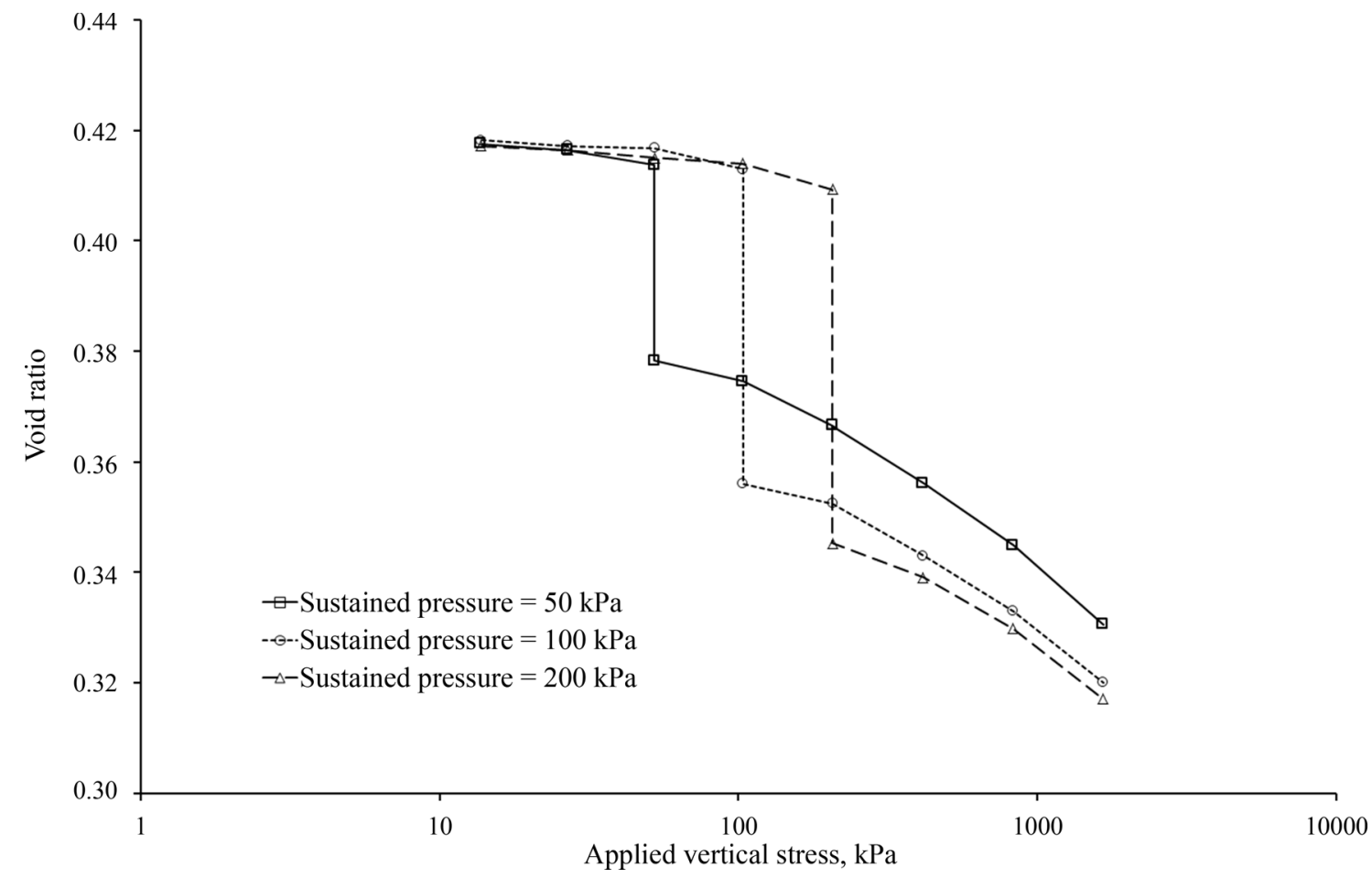

Figure 12 - Void ratio vs. applied stress curves for different sustained pressures.

creases with increasing sustained pressure (Fig. 12), which are consistent with those published in the literature for loessial soils (e.g. Lawton et al., 1989) and for sabkha soils in Saudi Arabia (Al-Amoudi \& Abduljauwad, 1995).
Moreover, the collapse potential is likely to be significant even for relatively small values of the applied load, which implies that the collapse may be a concern even for lower embankment heights. 


\section{Conclusions}

The results of compaction tests indicate the significant effect of water salinity on the compaction characteristics of the sabkha soil. The use of conventional water content procedure to plot the compaction curve overestimates the maximum dry unit weight and underestimates the optimum moisture content. Moreover, the maximum dry unit weight is less affected by the type of fluid and method used to determine the compaction curve compared to the optimum moisture content.

Therefore, for the case of saline soils, it seems more logical to use the fluid content method to determine the compaction characteristics than the conventional water content procedure.

The results of collapsibility tests indicate the ability of the modified oedometer to detect the collapse potential of saline soils. The salt plays the role of cementing agent in dry condition and may dissolve upon wetting and percolation by distilled water causing collapse. This implies that the conventional oedometer cannot be used to assess the collapse potential of saline soils.

The collapsible potential on the wet side is greater than that on the dry side of optimum and the minimum value of collapsibility of the studied soil was found on the dry side of optimum at a relative compaction of about $95 \%$. Therefore, when a saline soil is intended to be used as a fill or embankment, it is recommended to compact the soil on the dry side of the optimum in order to reduce the risk of collapse after inundation.

The amount of collapse potential seems to depend on relative compaction, fluid content, degree of saturation and applied load. Higher collapse potential is observed in the specimens with higher fluid content and degree of saturation and lower relative compaction. In addition, collapse potential increases with increasing applied load.

The results presented here should be confirmed by further studies on different types of saline soils.

\section{References}

Al-Amoudi, O.S.B. \& Abduljauwad, S.N. (1995). Compressibility and collapse characteristics of arid saline sabkha soils. Engineering Geology, 39(3-4):185-202. https://doi.org/10.1016/0013-7952(95)00016-9

Alainachi, I.H. \& Alobaidy, G.A. (2010). The effects of Basra gulf salt water on the proctor compaction and CBR test results of soil samples at Baniyas City, Abu Dhabi, UAE. Electronic Journal of Geotechnical Engineering (EJGE), 15(A):1-14. http://www.ejge.com/2010/Ppr10.001.pdf

Amin, A. (2004). Comparative study of the geotechnical properties of the coastal Sabkhas of Saudi Arabia and their hazardous effects. Bull Eng Geol Env., 63:309314. https://doi.org/10.1007/s10064-004-0254-5
ASTM (2003). Standard Test Methods for Measurement of Collapse Potential of Soils- D-5333. Annual Book of ASTM Standards. https://doi.org/10.1520/D5333-03

ASTM (2005). Standard Test Methods for Specific Gravity of Soil Solids by Water Pycnometer- D854-05. Annual Book of ASTM Standards. https://doi.org/10.1520/D0854-05

ASTM (2007). Standard Test Methods for Particle-Size Analysis of Soils - D422-63. Annual Book of ASTM Standards. https://doi.org/10.1520/D0422-63R07E02

ASTM (2007). Standard Test Methods for Laboratory Compaction Characteristics of Soil Using Standard Effort (12 $400 \mathrm{ft}-\mathrm{lbf} / \mathrm{ft} 3$ (600 kN-m/m3) - D-698. Annual Book of ASTM Standards. https://doi.org/10.1520/D0698-12E02

Khan, M.Y. \& Hasnain, S.I. (1981). Engineering properties of sabkha soils in the Bengazi plain and construction problems. Engineering Geology, 17:175-183. https://doi.org/10.1016/0013-7952(81)90082-X

Lawton, E.C.; Fragaszy, R.J. \& Hardcastle, J.H. (1989). Collapse of compacted clayey sand. Journal of Geotechnical Engineering, 9:1252-1267. https://doi.org/10.1061/(ASCE)0733-9410(1989)115:9 (1252)

Lawton, E.C.; Fragaszy, R.J. \& Hetherington, M.D. (1992). Review of wetting induced collapse in compacted soils. Journal of Geotechnical Engineering, 118(9):1376-1392. https://doi.org/10.1061/(ASCE)0733-9410(1992)118:9 (1376)

Mansour, Z.M.; Taha, M.R. \& Chik, Z. (2008). Fresh-brine water effect on the basic engineering properties of Lisan Marl-Dead Sea-Jordan. Journal of Applied Sciences 8:3603-3611. https://doi.org/10.3923/jas.2008.3603.3611

Moayed, R.Z.; Izadi, E. \& Heidari, S. (2010). Improvement of saline silty sand soil behavior using lime and micro silica. Proc. Fifth Civil Engineering Conference in the Asian Region and Australasian Structural Engineering Conference. Sydney, pp. 466-473.

Messad, A. \& Moussai, B. (2016a). Effect of water salinity on Atterberg limits of El-Hodna sabkha soil. Bulletin of Engineering Geology and the Environment, 75:301309. https://doi.org/10.1007/s10064-015-0733-x

Messad, A. \& Moussai, B. (2016b). Evaluation of the collapsibility of El Hodna Sabkha soil - Algeria. Proc. Fourth Geo-China International Conference, Shandong, China 25-27 July, pp. 278-28. https://doi.org/10.1061/9780784480083.034

Shariatmadari, N.; Salami, M. \& Karimpour Fard, M. (2011). Effect of inorganic salt solutions on some geotechnical properties of soil-bentonite mixtures as barriers. International Journal of Civil Engineering, 9:103-110. http://ijce.iust.ac.ir/article-1-570-en.html 